\title{
Dopamine Enhances EPSCs in Layer II-III Pyramidal Neurons in Rat Prefrontal Cortex
}

\author{
Carlos Gonzalez-Islas and John J. Hablitz \\ Department of Neurobiology and Civitan International Research Center, University of Alabama at Birmingham, Birmingham, Alabama 35294
}

Dopaminergic inputs to the prefrontal cortex (PFC) are important for the integration of neuronal signals, the formation of working memory, and the establishment of memory fields. A detailed characterization of cellular mechanisms underlying the effects of dopamine on PFC is still emerging. We have examined how dopamine affects excitatory synaptic transmission in the PFC using whole-cell patchclamp recording from visually identified layer II-III pyramidal cells in vitro. Bath application of dopamine significantly enhanced EPSC amplitudes. Pharmacologically isolated AMPA and NMDA receptor-mediated EPSCs were increased to a similar extent. Application of the specific D1-like receptor agonist SKF38393 [( \pm )-1-phenyl-2,3,4,5-tetrahydro-(1H)-3-benzazepine-7,8-diol hydrobromide] significantly increased EPSC amplitude, whereas the D2-like receptor agonist quinpirole had no effect. Responses to pressure-applied glutamate were also enhanced by dopamine, indicating a postsynaptic mechanism. Inclusion of the $\mathrm{Ca}^{2+}$ chelator BAPTA in the recording pipette blocked the dopamine enhancement. When the PKA inhibitory peptide PKI [5-24] was included in the recording pipette, dopamine did not affect EPSCs. Similarly, when the $\mathrm{Ca}^{2+} /$ calmodulin-kinase II (CaMKII) inhibitory peptide was present in the pipette, dopamine enhancement of EPSCs was not observed in any of the cells tested. These results indicate that EPSC enhancement may be attributable to a postsynaptic signaling cascade involving $\mathrm{Ca}^{2+}$, PKA, and CaMKII.

Key words: neocortex; dopamine; EPSCs; NMDA; AMPA; modulation; D1

\section{Introduction}

Dopaminergic inputs to the prefrontal cortex (PFC) have been known for some time to be important for integration of neuronal signals, the formation of working memory (Sawaguchi and Goldman-Rakic, 1994), and the establishment of memory fields (Williams and Goldman-Rakic, 1995). Despite this, a detailed characterization of cellular mechanisms underlying the effects of dopamine on the PFC is still emerging. In vivo recordings have shown that the spontaneous firing rate of PFC neurons is depressed by dopamine or stimulation of the ventral tegmental area (Bunney and Aghajanian, 1976; Ferron et al., 1984; Sawaguchi and Matsumura, 1985; Sesack and Bunney, 1989, Yang and Mogenson, 1990; Pirot et al., 1992; Thierry et al., 1992). AMPA receptor-mediated EPSPs in layer V pyramidal cells are decreased by activation of D1 receptors (Law-Tho et al., 1994; Seamans et al., 2001), whereas NMDA receptor-mediated responses have been reported to be both increased (Seamans et al., 2001) and decreased (Law-Tho et al., 1994). Dopamine also enhances the induction of long-term depression in layer V cells (Law-Tho et al., 1995; Otani et al., 1998). D4 receptor-deficient mice display cortical hyperexcitability, suggesting that D4 receptors could function as inhibitory modulators of glutamate activity (Rubinstein et al., 2001). In contrast to these inhibitory actions, dopamine potentiated responses to subthreshold doses of NMDA and acetylcholine (Yang and Mogenson, 1990; Cepeda et al., 1992). During short-term working memory processing, a dopamine-

\footnotetext{
Received 0ct. 9, 2002; revised Nov. 19, 2002; accepted Nov. 20, 2002.

This work was supported by National Institutes of Health Grants NS18145 and HD38985. We thank Dr. Joel Gallagher for reading this manuscript.

Correspondence should be addressed to Dr. John J. Hablitz, Department of Neurobiology, University of Alabama at Birmingham, Birmingham, AL 35294. E-mail:jhablitz@uab.edu.

Copyright $\odot 2003$ Society for Neuroscience $\quad 0270-6474 / 03 / 230867-09 \$ 15.00 / 0$
}

dependent increase in firing of PFC neurons has been observed (Fuster, 1995; Goldman-Rakic, 1995). D1 receptors also seem to be crucial for the NMDA receptor-dependent long-term potentiation (LTP) at hippocampal-PFC synapses (Gurden et al., 2000). Similarly, activation of D1/D5 receptors is required for LTP induction in corticostriatal pathways (Kerr and Wickens, 2001).

Dopamine reduces excitation in specific classes of inputs onto layer III pyramidal neurons in primate PFC (Urban et al., 2002). Dopamine had no effect on miniature EPSCs (mEPSCs) in layer II-III PFC pyramidal neurons (Zhou and Hablitz, 1999) but had multiple effects on IPSCs. Dopamine increased the excitability of GABAergic interneurons (Zhou and Hablitz, 1999), whereas evoked IPSCs were reduced (Gonzalez-Islas and Hablitz, 2001). These results suggest that dopamine may differentially modulate spontaneous and evoked release of neurotransmitter, as reported for other neuromodulators (Pitler and Alger, 1992; Scanziani et al., 1992, 1993; Kondo and Marty, 1998).

In primates (Lewis et al., 1998) and rodents (Berger et al., 1991), the density of dopaminergic axons varies as a function of cortical layer and cytoarchitectonic region. The distinctive laminar and regional distribution patterns of dopamine innervation raise the question of whether dopaminergic axons target specific subclasses of neurons. Pyramidal neurons may express different subtypes of dopamine receptors (Vincent et al., 1993, 1995; Mrzljak et al., 1996), providing an additional basis for differential dopamine modulation of cortical neurons. Layer II-III pyramidal neurons are the source of significant intracortical horizontal pathways (Hess et al., 1994). Because superficial layers of rat PFC receive a substantial dopamine input (Gaspar et al., 1995; Lu et al., 1997), we have examined the effects of dopamine on EPSCs in layer II-III pyramidal cells. The present results indicate that do- 
pamine can enhance EPSCs in upper cortical layers. A postsynaptic mechanism involving activation of D1-like receptors appears to be involved. A preliminary report of some of these results has been published previously in abstract form (Gonzalez-Islas and Hablitz, 2000).

\section{Materials and Methods}

Slice preparation. Neocortical slices were prepared from Sprague Dawley rats (15-25 d of age). Animals were handled and housed according to the guidelines of the National Institutes of Health Committee on Laboratory Animal Resources. All experimental protocols were approved by the Institutional Animal Care and Use Committee. Every effort was made to minimize pain and discomfort. Rats were anesthetized with ketamine and decapitated. The brain was removed quickly and placed in ice-cold artificial CSF (ACSF), which contained (in $\mathrm{mM}$ ): $125 \mathrm{NaCl}, 3.5 \mathrm{KCl}, 0.5$ $\mathrm{CaCl}_{2}, 3.5 \mathrm{MgCl}_{2}, 26 \mathrm{NaHCO}_{3}$, and $10 \mathrm{D}$-glucose. The solution was bubbled with $95 \% \mathrm{O}_{2} / 5 \% \mathrm{CO}_{2}$ to maintain a pH of $\sim 7.4$. Coronal brain slices (300 $\mu \mathrm{m}$ thick) were cut using a Vibratome. The anterior cingulate cortex and the shoulder or Fr2 region of the frontal cortex (Paxinos and Watson, 1986) were used for recording, as shown in Figure $1 \mathrm{~A}$. These two areas make up a large portion of the rodent PFC (Kolb, 1990). The slices were incubated in ACSF similar to that described above but containing $2.5 \mathrm{~mm}$ $\mathrm{CaCl}_{2}$ and $1.3 \mathrm{mM} \mathrm{MgCl}_{2}$, bubbled with a mixture of $95 \% \mathrm{O}_{2} / 5 \% \mathrm{CO}_{2}$, for at least $1 \mathrm{hr}$ at room temperature $\left(22^{\circ} \mathrm{C}\right)$ before recording. After incubation, slices were transferred to a recording chamber continuously perfused ( $3 \mathrm{ml} / \mathrm{min}$ ) with oxygenated ACSF. A Zeiss (Thornwood, NY) Axioskop upright microscope, equipped with Nomarski optics, a $40 \times$ water immersion lens, and infrared illumination was used to view neurons in the slices. Layer II-III pyramidal neurons were identified by their pyramidal shape, presence of a prominent apical dendrite, distance from the pial surface, and their regular spiking properties. In some experiments, cells were intracellularly labeled with biocytin to confirm identification. Labeled cells were processed as described previously (Zhou and Hablitz, 1996).

Whole-cell recording. Whole-cell voltage-clamp recordings were obtained as described previously (Gonzalez-Islas and Hablitz, 2001). Tight seals ( $>2 \mathrm{G} \Omega$ before breaking into whole-cell mode) were obtained without first cleaning the cell. Patch electrodes had an open tip resistance of $\sim 3 \mathrm{M} \Omega$. Series resistance during recording varied from 10 to $20 \mathrm{M} \Omega$ and was not compensated. Recordings were terminated whenever significant increases $(>20 \%)$ in series resistance occurred. The intracellular solution for recording synaptic currents contained (in mM): $125 \mathrm{~K}$-gluconate, 10 $\mathrm{KCl}, 10$ HEPES, $2 \mathrm{Mg}$-ATP, $0.2 \mathrm{Na}-\mathrm{GTP}$, and 0.5 EGTA. pH and osmolarity were adjusted to 7.3 and $285 \mathrm{mOsm}$, respectively. In some experiments, an intracellular solution was used in which $10 \mathrm{~mm}$ BAPTA was substituted for EGTA. After breaking into the cell, at least 15 min was allowed for BAPTA to diffuse into the cell. Bicuculline methiodide (10 $\mu \mathrm{M}$ ) (Sigma, St. Louis, MO) was bath applied to block $\mathrm{GABA}_{\mathrm{A}}$ receptormediated IPSCs. Synaptic responses were evoked with a bipolar stimulating electrode (twisted pair of $25 \mu \mathrm{m}$ Formvar-insulated nichrome wires) positioned $150-200 \mu \mathrm{m}$ subjacent to the recording pipette. Stimuli were current pulses $50-100 \mu \mathrm{A}$ in amplitude and $50-100 \mu \mathrm{sec}$ in duration. A stimulation frequency of $0.05 \mathrm{~Hz}$ was used. All traces of synaptic currents shown represent the average of 10 consecutive responses. Recordings were done at room temperature $\left(\sim 22^{\circ} \mathrm{C}\right)$.

Data collection and analysis. Signals were acquired using a Warner PC505A amplifier (Warner Instruments, Hamden, CT) controlled by Clampex 8.0 software (Axon Instruments, Foster City, CA) via a Digidata 1200B interface (Axon Instruments). Responses were filtered at $5 \mathrm{kHz}$, digitized at $10-20 \mathrm{kHz}$, and analyzed using Clampfit 8.0 software (Axon Instruments). Data are expressed as mean \pm SEM. Statistical analysis of response amplitudes before, during, and after addition of dopaminergic agents was carried out using a two-tailed Student's $t$ test. $p<0.05$ was considered significant. Dose-response data were fitted to an unconstrained Hill function using Clampfit.

Drug application. Dopamine was used as the endogenous agonist for dopamine receptors and was bath applied. After collecting control responses, dopamine and dopaminergic agonists were bath applied. After 4 min of drug application, experimental data were obtained. Acquisition consisted of 10-12 consecutive responses at $0.05 \mathrm{~Hz}$. Drug free solution was then applied for $10 \mathrm{~min}$, and wash responses were recorded. Antagonists were applied $20 \mathrm{~min}$ before acquiring control records as well as during agonist application. ( \pm )-1-phenyl-2,3,4,5-tetrahydro- $(1 \mathrm{H})-3$ benzazepine-7,8-diol hydrobromide (SKF38393) and $R(+)$-7-chloro-8hydroxy-3-methyl-1-phenyl-2,3,4,5-tetrahydro-1H-3-benzazepine hydrochloride (SCH23390) hydrochloride were used as selective D1-like agonists and antagonists, respectively. Quinpirole and $(R S)-( \pm)-$ sulpiride were used as selective D2-like agonists and antagonists, respectively. All of these agents were purchased from Tocris Cookson (Ellisville, $\mathrm{MO})$. In paired-pulse experiments, the $\mathrm{GABA}_{\mathrm{B}}$ receptor antagonist $(2 S)$ (+)-5,5-dimethyl-2-morpholineacetic acid (SCH50911) (Tocris Cookson) was included in bathing solution. Drugs were stored in frozen stock solution and dissolved in the ACSF before each experiment. Sodium metabisulfite $\left(\mathrm{Na}_{2} \mathrm{~S}_{2} \mathrm{O}_{5}, 50 \mu \mathrm{M}\right)$ was used to protect dopamine and dopaminergic agonists and antagonists from oxidation (Sutor and Ten Bruggencate, 1990).

Peptide inhibitors of $\mathrm{Ca}^{2+} /$ calmodulin kinase II (CaMKII inhibitor 281-309) and PKA [protein kinase inhibitor (PKI) [5-24]] were obtained from Calbiochem (La Jolla, CA). For application, these agents were included in the patch pipette.

Under direct visual guidance, glutamate $(250 \mu \mathrm{M}$ or $1 \mathrm{~mm})$ was pressure applied to the soma of the neuron and proximal dendrite from a distance of $\sim 10 \mu \mathrm{m}$. Pipettes for pressure applications were fabricated in the same manner as the patch electrodes described above. Glutamate was applied in a solution consisting of $125 \mathrm{NaCl}, 3.5 \mathrm{KCl}, 20 \mathrm{HEPES}$, and 10 D-glucose, pH 7.3 with $\mathrm{NaOH}$. Pressure applications were controlled using a Picospritzer II (General Valve, Fairfield, NJ). Pulses were 5-15 msec in duration and were delivered at 3-12 psi. Settings were kept constant during a given recording. Glutamate pulses were given at $1 \mathrm{~min}$ intervals. All responses to glutamate shown represent the average of 10 consecutive applications. Application of the pressure pipette solution without glutamate did not evoke any detectable response.

\section{Results}

A photomicrograph of a slice used for recording is shown in Figure $1 A$. The area used for recording is outlined by a box. Figure $1 B$ shows a low-power photomicrograph of a biocytinlabeled pyramidal cell. A camera lucida drawing of the neuron is shown in Figure $1 C$. Under direct visualization, 145 layer II-III pyramidal neurons from the anterior cingulate cortex and PFC (referred to as PFC pyramidal neurons) were recorded. Significant differences in the effect of dopamine between neurons recorded in the two areas were not observed, and the results were pooled for analysis.

\section{Dopamine and EPSCs}

After reaching a stable whole-cell configuration, intracortical stimulation of increasing intensity was given until a consistent
A

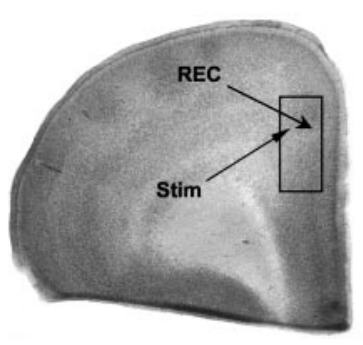

$\mathbf{B}$

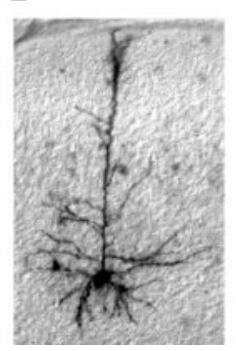

C

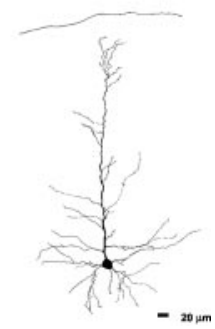

Figure 1. Identification of neurons in the PFC. A, Photomicrograph of a cresyl violet-stained section from a slice used for recording. The box indicates the area typically used for recording. The location of the stimulation (Stim) and recording electrode (REC) is also shown. B, Photomicrograph of a biocytin-labeled layer II-III PFC pyramidal neuron. C, Camera lucida reconstruction of the neuron in $B$. 

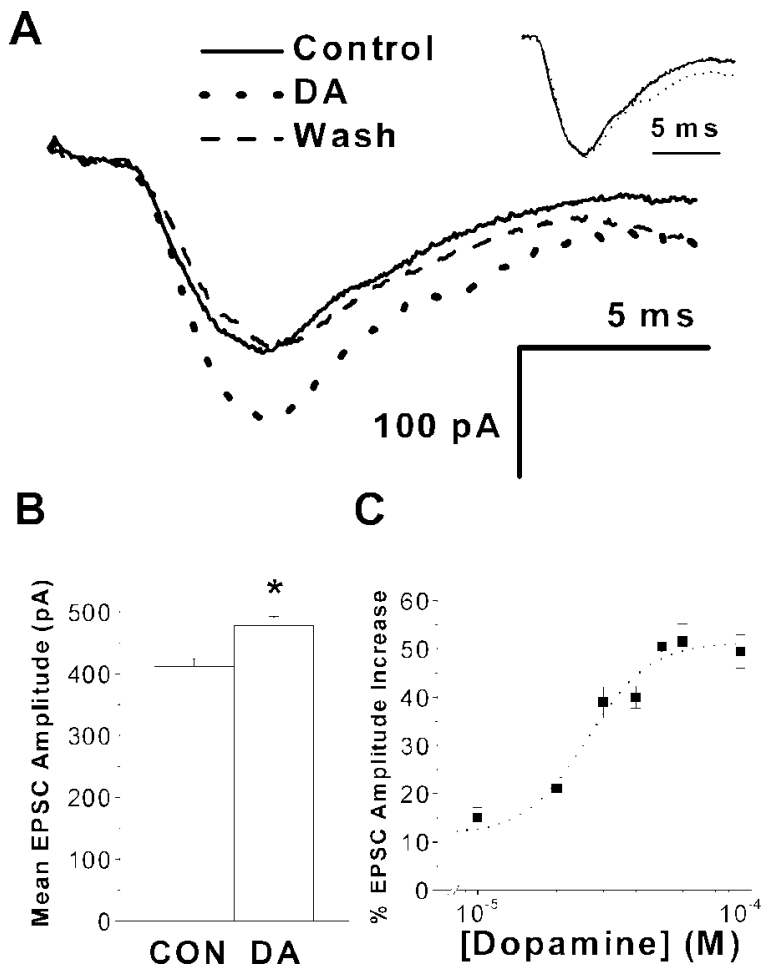

Figure 2. Dopamine (DA) increases EPSC amplitude in PFC pyramidal neurons. A, Superimposed traces of representative averaged EPS(s before (solid line), during (dotted line), and after (dashed line) bath application of $20 \mu \mathrm{m}$ dopamine. No significant change in holding current was observed before or after dopamine addition. A holding potential of $-70 \mathrm{mV}$ was used. The inset shows EPSCs under control (solid line) and dopamine (dotted line) conditions scaled to the same peak amplitude. No significant change in decay time constant was observed. B, Plot of averaged EPSC amplitude under control conditions (CON) and in the presence of $20 \mu \mathrm{m}$ dopamine $(n=$ 20 cells). An increase of $16 \%$ in EPSC amplitude was observed. The asterisk indicates a significant difference compared with controls. C, Dose-response relationship for dopamine-induced increases in EPSC amplitude. Each point represents the average of five experiments. The fitted curve (dotted line) was calculated with a Hill function ( $\mathrm{EC}_{50}$ of $\left.26.1 \mu \mathrm{m}\right)$. Results are showed as mean \pm SEM

response was evoked. After a latency of $2.14 \pm 0.2 \mathrm{msec}$, an inward current was observed. Response amplitude varied from 46 to $750 \mathrm{pA}$ in different cells. Bath application of $20 \mu \mathrm{M} \mathrm{D}-2$-amino5-phosphovaleric acid (D-APV) and $10 \mu \mathrm{M}$ 6-cyano-7nitroquinoxaline-2,3-dione (CNQX) completely suppressed these currents (data not shown) indicating that they are glutamate-mediated EPSCs. EPSCs had a half rise time of $1.36 \pm$ $0.2 \mathrm{msec}(n=20)$ and relaxed with a single exponential time course. The decay time constant was $5.27 \pm 1.5 \mathrm{msec}(n=20)$. Typical responses are shown in Figure $2 A$. After bath application of $20 \mu \mathrm{M}$ dopamine, EPSC amplitudes were significantly enhanced by $16 \%(411.5 \pm 13$ vs $477.5 \pm 15$ pA; $n=20 ; p<0.05)$, as shown in Figure $2 B$. Responses scaled to the same peak amplitude were superimposable (Fig. $2 \mathrm{~A}$, inset), suggesting that dopamine did not affect EPSC kinetics. The half rising time $(1.4 \pm 0.3$ msec; $n=20 ; p>0.9)$ and decay time constant $(5.4 \pm 1.3 \mathrm{msec}$; $n=20 ; p>0.8)$ were not significantly altered after adding dopamine. Washout of dopamine for $10 \mathrm{~min}$ reversed the observed increase in EPSC amplitude (Fig. 2A).

The effect of varying the concentration of dopamine was tested. The dopamine-induced increase in EPSC amplitude was concentration-dependent between 1 and $100 \mu \mathrm{M}$ dopamine. Figure $2 C$ depicts the concentration-response relationship. Each point represents average data from five neurons. Fitting the ex-

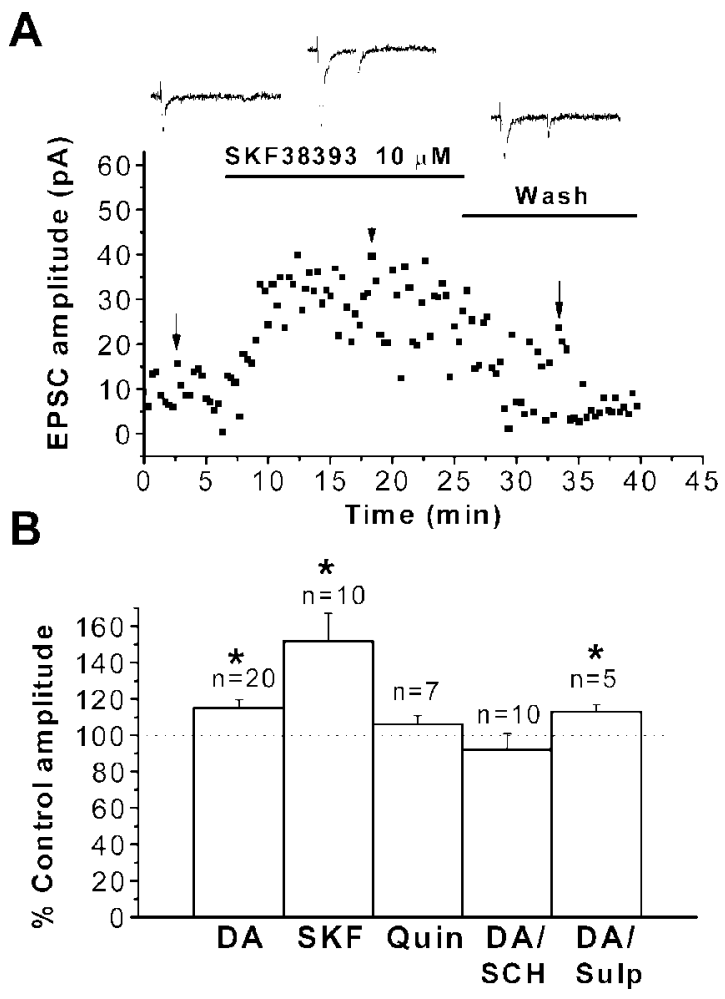

Figure 3. Effect of dopaminergic agonists and antagonists on neocortical EPSCS. A, Representative experiment showing the time course of the D1-like specific agonist SKF38393 effects. Plot of EPSC amplitude as a function of time shows that agonist application produces a rapid and sustained EPSC increase. The effect was reversible with washing. The inset shows representative traces of EPSC s obtained at times indicated by arrows. A holding potential of $-70 \mathrm{mV}$ was used throughout. $B$, Summary of results with bath application of dopaminergic agonists and antagonists. Results are expressed as a percentage of control EPSC amplitude. The dopamine (DA) concentration was $20 \mu \mathrm{m}$. Bars represent mean \pm SEM. Asterisks indicate a significant difference compared with controls. The horizontal dotted line indicates control amplitude. SKF, SKF38393; Quin, quinpirole; SCH, SCH23390; Sulp, sulpiride.

perimental points to an unconstrained Hill function, we obtained an $\mathrm{EC}_{50}$ of $26.1 \mu \mathrm{M}$. The maximum enhancement of the EPSC amplitude was $51.4 \%$. The effect of dopamine showed saturation at $\sim 100 \mu \mathrm{M}$. No desensitization was observed when dopamine was added repeatedly after at least $10 \mathrm{~min}$ washout intervals (data not shown).

The observed EPSC enhancement could be attributable to a generalized increase in excitability caused by a change in input resistance or repetitive firing properties. This is unlikely, because we have shown previously that dopamine does not significantly affect the resting potential or repetitive firing properties of layer II-III pyramidal cells (Zhou and Hablitz, 1999; Gonzalez-Islas and Hablitz, 2001). In the present study, dopamine was not observed to significantly change the holding current under voltageclamp conditions $(15.4 \pm 3 \mathrm{pA}$ for control vs $14.7 \pm 3 \mathrm{pA}$ for dopamine; $n=20 ; p>0.5)$.

\section{Role of specific dopamine receptor subtypes}

The effects of specific dopamine receptor agonists and antagonists were tested to elucidate the receptor subtypes mediating dopamine-induced EPSC amplitude enhancement. As shown in Figure $3 A$, bath application of the specific D1-like receptor agonist SKF38393 $(10 \mu \mathrm{M})$ increased EPSC amplitude. Specimen records of averaged EPSCs before, during, and after bath application are shown. A plot of EPSC amplitude as a function of time indicates that SKF38393 produced a prompt increase in EPSC 


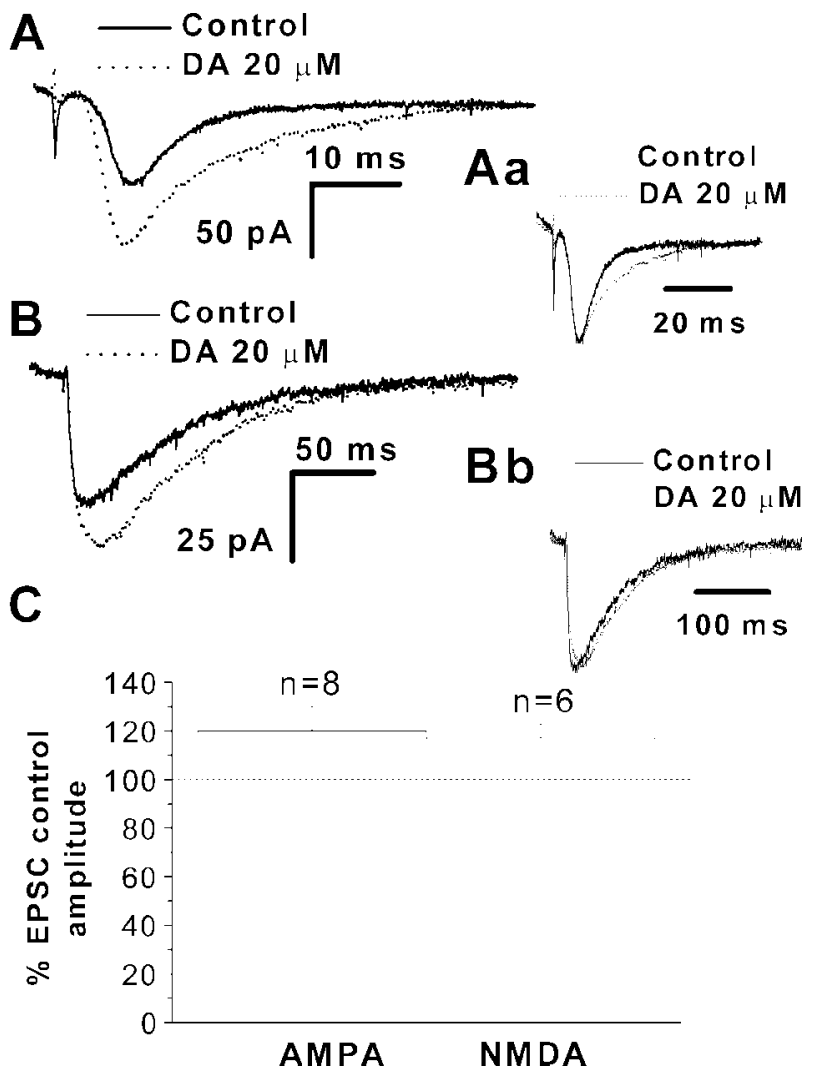

Figure 4. Action of dopamine on AMPA- and NMDA-mediated EPSCS. A, Superimposed traces of AMPA receptor-mediated EPSCS recorded from a PFC pyramidal cell before (solid line) and during (dotted line) application of $20 \mu \mathrm{M}$ dopamine (DA). EPSCs were increased during dopamine application. Bicuculline (Bic) and D-AP-5 were present to block GABA $A_{A}$ and NMDA receptor-mediated responses, respectively. The holding potential was $-70 \mathrm{mV}$. Aa, AMPAmediated EPSCs under control conditions (solid line) and during dopamine addition (dotted line), scaled to the same peak amplitude. Decay time was prolonged. B, Superimposed traces of NMDA receptor-mediated EPSCs before (solid line) and during (dotted line) addition of $20 \mu \mathrm{m}$ dopamine. Bic and CNQX were used to block $G A B A_{A}$ - and AMPA-mediated responses, respectively. Holding potential was $-40 \mathrm{mV}$ to decrease the voltage-dependent $\mathrm{Mg}^{2+}$ block of NMDA channels. Bb, Scaling NMDA-mediated EPSC under control (solid line) and during dopamine (dotted line) to the same peak amplitude indicates that decay time constants were not significantly affected. C, Bar graph summarizing results with AMPA and NMDA receptormediated EPSCs. The horizontal dotted line indicates control amplitude.

amplitude that partially reversed with washing. Averaged EPSCs were obtained at the time indicated by the downward arrows. In 10 neurons, SKF38393 significantly increased EPSC amplitude $(51 \pm 15 \% ; n=15 ; p<0.04)$ (Fig. $3 B)$. The increase in EPSC amplitude by SKF38393 was significantly larger than that induced by $20 \mu \mathrm{M}$ dopamine $(p<0.05 \%)$ but not different from that obtained with $100 \mu \mathrm{M}$ dopamine.

In contrast to SKF38393, the D2-like receptor agonist quinpirole $(10 \mu \mathrm{M})$ had no significant effect on EPSC amplitude $(105.5 \pm 5 \% ; n=7 ; p>0.5)$ (Fig. 3B). The average EPSC half rising time $(1.4 \pm 0.1 \mathrm{msec}, p>0.8$ in SKF38393; $1.4 \pm 0.4 \mathrm{msec}$, $p>0.7$ in quinpirole) and decay time constant $(4.6 \pm 0.7 \mathrm{msec}$, $p>0.7$ in SKF38393; $4.4 \pm 0.3 \mathrm{msec}, p>0.5$ in quinpirole) were not affected by either agonist. These results suggest that dopamine acted on D1-like receptors to produce the observed increase in EPSC amplitude.

To confirm D1-like receptor involvement, we examined the ability of the specific D1-like antagonist SCH23390 and the specific D2-like antagonist sulpiride to block dopamine-dependent enhancement of EPSCs. Antagonists were perfused for $20 \mathrm{~min}$
A

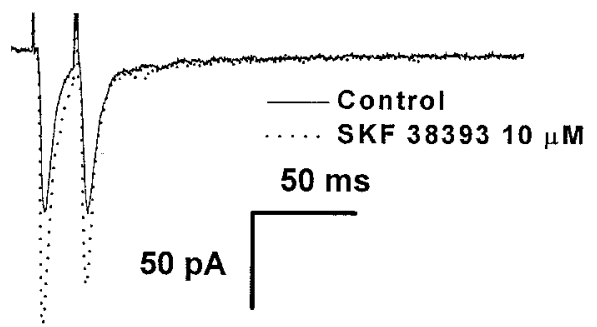

B

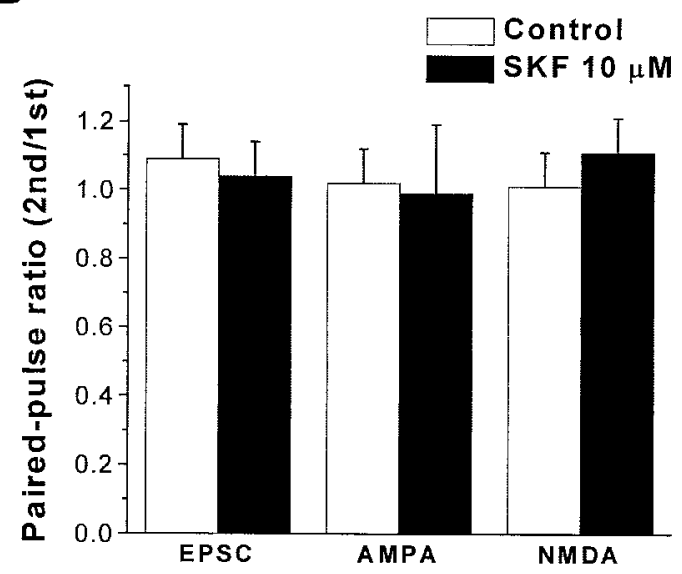

Figure 5. Responses to paired-pulse stimulation are not significantly affected by D1-like receptor activation. Recordings were made in the presence of bicuculline methiodide (10 $\mu \mathrm{m})$ to block $\mathrm{GABA}_{\mathrm{A}}$ currents and SCH50911 $(20 \mu \mathrm{m})$ to block $\mathrm{GABA}_{\mathrm{B}}$ receptors. The interpulse interval was 20 msec in all cases. $A$, Specimen records of AMPA-mediated EPSCs in response to paired stimulation before and after application of SKF38393. B, Summary of paired-pulse experiments. D-AP-5 $(20 \mu \mathrm{M})$ was added to block NMDA-mediated responses when recording AMPAmediated responses. CNQX (10 $\mu \mathrm{m}$ ) was used to block AMPA-mediated responses when recording NMDA-mediated responses. For the first two conditions, the holding potential was -70 $\mathrm{mV}$, while for NMDA EPSCs, the holding potential was $-40 \mathrm{mV}$ to relieve the voltagedependent $\mathrm{Mg}^{2+}$ block of NMDA channels. Dopamine $(D A)$ had no significant effect on the paired-pulse ratio.

while EPSCs were evoked at $20 \mathrm{sec}$ intervals. Responses were then recorded after this 20 min period of antagonist application, and dopamine was subsequently added in the continuous presence of the antagonist. Bath application of either antagonist had no effect on EPSC amplitude (160.6 \pm 28 pA for control vs $159.5 \pm 28 \mathrm{pA}$ for SCH23390; $149.5 \pm 22 \mathrm{pA}$ for control vs $148.8 \pm 21 \mathrm{pA}$ for sulpiride). Holding current at $-70 \mathrm{mV}$ was also unaffected $(-61.5 \pm 10 \mathrm{pA}$ for control vs $-62.7 \pm 12 \mathrm{pA}$ for SCH $23390, n=$ $10, p>0.8 ;-82.5 \pm 33 \mathrm{pA}$ for control vs $-79.9 \pm 30 \mathrm{pA}$ for sulpiride, $p>0.06)$, In the presence of sulpiride $(20 \mu \mathrm{M})$, dopamine enhanced EPSCs $(13 \pm 5 \% ; n=5 ; p<0.01)$ in a manner similar to that observed in absence of the D2 antagonists (Fig. $3 B$ ). Conversely, when D1-like dopamine receptors were blocked with the specific antagonist SCH23390 $(10 \mu \mathrm{M})$, EPSCs were not enhanced (Fig. 3B) (93 $\pm 6 \% ; p>0.1$ vs control in the presence of antagonist; $n=10)$.

\section{Dopamine effects on NMDA and AMPA receptor EPSCs}

EPSCs in PFC pyramidal neurons have both AMPA and NMDA receptor-mediated components. To determine whether dopamine selectively modulated individual EPSC components, as reported for layer V neurons (Seamans et al., 2001), AMPA and NMDA receptor-mediated EPSCs were pharmacologically isolated. Figure $4 A$ shows EPSCs recorded in the presence of $10 \mu \mathrm{M}$ bicuculline and $20 \mu \mathrm{M}$ D-AP-5. At a holding potential of $-70 \mathrm{mV}$, 

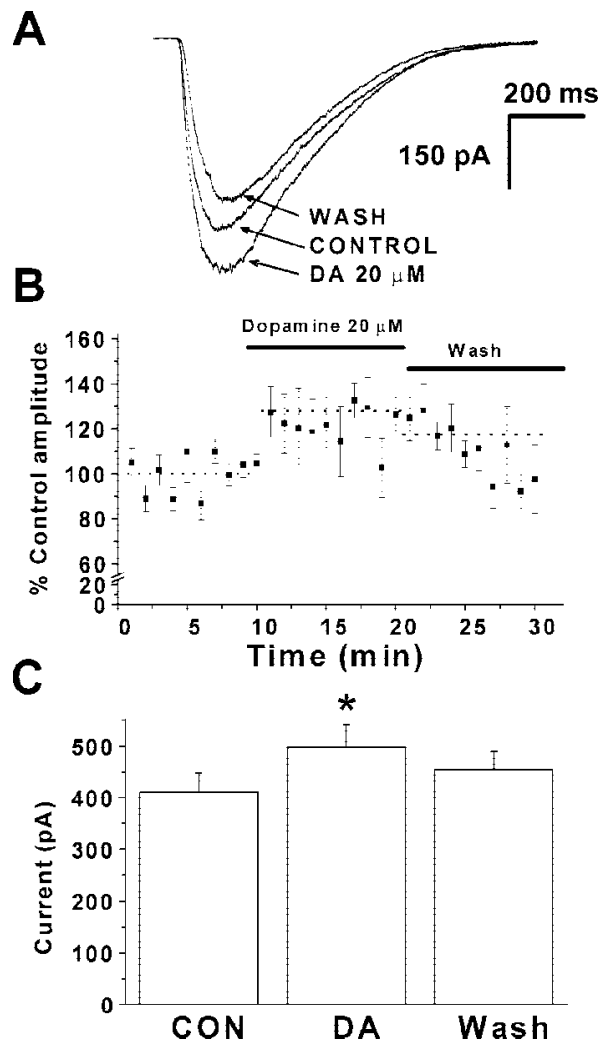

Figure 6. Dopamine enhances the response to directly applied glutamate. A, Representative experiment showing response to pressure application of glutamate in control conditions, during bath application of $20 \mu \mathrm{m}$ dopamine $(D A)$, and after washing for $10 \mathrm{~min}$. Each trace is the average of 10 glutamate applications. The membrane potential was held at $-70 \mathrm{mV}$. B, Plot of glutamate response amplitude as a function of time. Data from five cells was normalized. Dashed lines indicate average response levels before, during, and after dopamine application. C, Summary of the effect of dopamine on applied pressure evoked glutamate responses in five neurons. Dopamine was able to increase glutamate response amplitude ( $411 \pm 38 \mathrm{pA}$ in control vs $492.1 \pm 44 \mathrm{pA}$ in dopamine; $n=5 ; p<0.05)$. The asterisk indicates a significant difference compared with control (CON).

dopamine enhanced the amplitude of AMPA receptor-mediated EPSCs $(20 \pm 7 \% ; n=8 ; p<0.05)$ (Fig. $4 A, C$ ). The holding current (14.9 $\pm 3 \mathrm{pA}$ for control vs $14.6 \pm 4 \mathrm{pA}$ for dopamine; $n=8 ; p>0.05)$ and AMPA-mediated EPSC half rising time $(1.5 \pm 0.4 \mathrm{msec}$ for control vs $1.3 \pm 0.5 \mathrm{msec}$ for dopamine; $n=$ $8 ; p>0.05$ ) (Fig. $4 A a$ ) were unaffected. In six of eight cells, an increase in the decay time constant was observed $(6.2 \pm 2$ vs $10.6 \pm 2 \mathrm{msec}$ ) (Fig. 4Aa). In another group of cells, $10 \mu \mathrm{M}$ CNQX was used to block AMPA receptors and permit recording of an NMDA receptor-mediated EPSC. Neurons were held at $-40 \mathrm{mV}$ to partially relieve the voltage-dependent $\mathrm{Mg}^{2+}$ block of NMDA channels. Under these conditions, dopamine significantly increased the amplitude of NMDA-mediated EPSCs (17 \pm $4 \% ; n=6)($ Fig. $4 B, C)(p<0.05)$ without changing EPSC kinetics. No change in half rise time $(2.1 \pm 0.5 \mathrm{msec}$ for control vs $2.4 \pm 0.6$ msec for dopamine; $n=6 ; p>0.7$ ) (Fig. $4 B b$ ) or decay time constant $(59.9 \pm 1 \mathrm{msec}$ for control vs $61.9 \pm 1 \mathrm{msec}$ for dopamine; $n=6 ; p>0.4$ ) (Fig. $4 B b$ ) was observed. Holding current was also unaffected by dopamine addition $(20.12 \pm 3.5$ pA for control; $20.52 \pm 4.2 \mathrm{pA}$ for dopamine; $n=6$; $p>0.9$ ). These results suggest that both AMPA and NMDA receptormediated EPSCs are enhanced to a similar extent by dopamine.
A

B

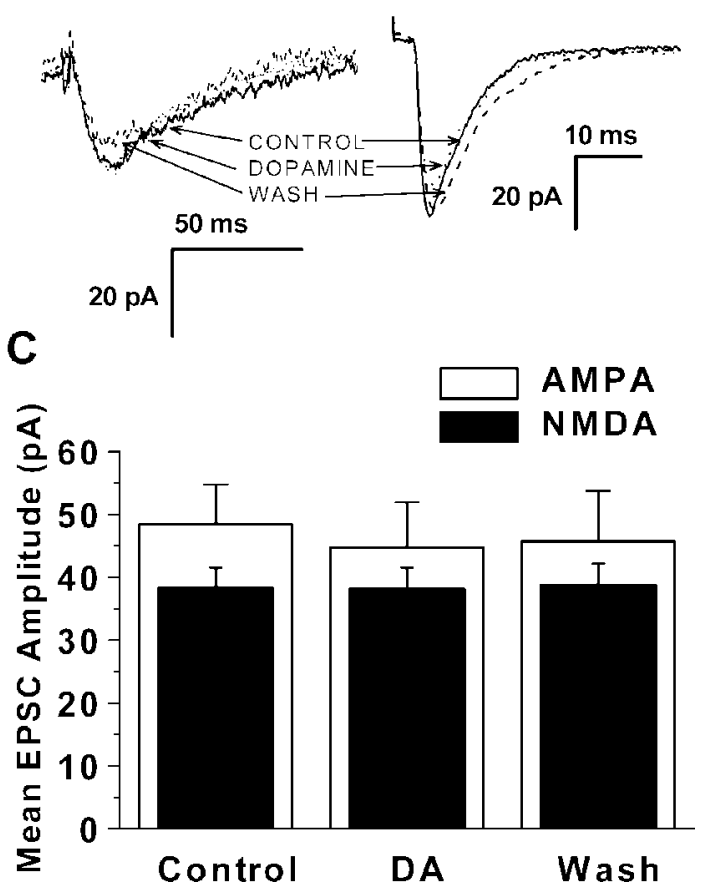

Figure 7. Chelation of internal $\left[\mathrm{Ca}^{2+}\right]$ prevents EPSC enhancement by dopamine. Recordings of EPSCs were obtained with $10 \mathrm{~mm}$ BAPTA in the recording pipette. $A$, Superimposed traces of NMDA receptor-mediated EPSCs before, during, and $10 \mathrm{~min}$ after the addition of $20 \mu \mathrm{M}$ dopamine are shown. Holding potential was $-40 \mathrm{mV}$. B, AMPA receptor-mediated EPSCs before, during, and $10 \mathrm{~min}$ after dopamine $(20 \mu \mathrm{M})$ application are shown. BAPTA was present in the pipette. Holding potential was $-70 \mathrm{mV}$. C, Summary graph showing that when the $\mathrm{Ca}^{2+}$ chelator BAPTA was included in the pipette solution, dopamine (DA) did not significantly increase AMPA $(n=5)$ or NMDA $(n=5)$ receptor-mediated EPSCs.

\section{Site of action of dopamine}

Presynaptic

To determine whether the EPSC-enhancing action of dopamine is mediated by a presynaptic mechanism, we examined the effect of dopamine on the ratio of EPSC amplitudes evoked by paired stimulation. The $\mathrm{GABA}_{\mathrm{B}}$ receptor antagonist $\mathrm{SCH} 50911$ was bath applied to prevent activation of presynaptic GABA receptors, which can affect paired-pulse responses. Two stimuli were given at an interval of $20 \mathrm{msec}$, as shown in Figure $5 \mathrm{~A}$. A paired-pulse ratio was calculated by dividing the test EPSC amplitude by the control EPSC amplitude. Under control conditions, the pairedpulse ratio was $1.2 \pm 0.1$. Addition of $10 \mu \mathrm{M} \mathrm{SCH} 38393$, a selective D1-like agonist, did not significantly change the paired-pulse ratio $(1.04 \pm 0.1 \mathrm{SCH} 38393 ; n=7 ; p>0.9)$ (Fig. 5B). Similarly, SCH38393 had no effect on the paired-pulse ratio for isolated AMPA receptor-mediated EPSCs $(1.02 \pm 0.05$ for control vs $0.99 \pm 0.2$ for SCH38393; $n=6 ; p>0.15$ ) (Fig. $5 B$ ) or NMDA receptor-mediated EPSCs $(1.0 \pm 0.1$ vs $1.1 \pm 0.1 ; n=5 ; p>0.85)$ (Fig. 5B). These results suggest that dopamine receptordependent increases in EPSC amplitude are not caused by changes in presynaptic glutamate release, as reflected in responses to paired stimulation.

\section{Postsynaptic}

To investigate whether postsynaptic changes were involved in dopamine-induced EPSC enhancement, glutamate was locally applied from a pressure pipette while the neurons were held at $-70 \mathrm{mV}$. Figure $6 \mathrm{~A}$ shows averaged currents (10 responses) 
A

B
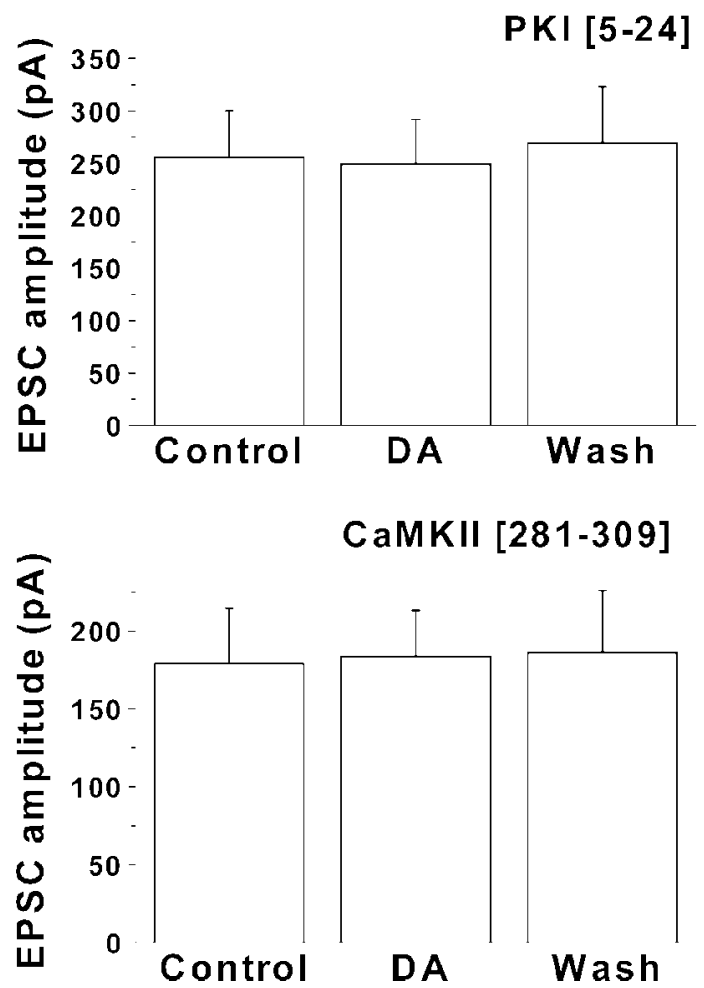

Figure 8. Role of PKA and CaMKII in EPSC enhancement. $A$, Summary graph for the effect of dopamine (DA) on EPSCs in five neurons recorded with a $1 \mu \mathrm{m}$ concentration of the PKA inhibitory peptide PKI [5-24] in the pipette solution. No significant changes in EPSC amplitude or kinetic properties were observed. A holding potential of $-70 \mathrm{mV}$ was used for these recordings. $B$, Summary of results with EPSCs in six neurons when a $10 \mu \mathrm{m}$ concentration of the CaMKII inhibitor peptide [281-309] was included in the internal solution. Blocking CaMKII in this way prevents dopamine-dependent EPSC enhancement. No significant differences were observed in either amplitude or kinetic properties during dopamine application.

evoked in one PFC pyramidal neuron by glutamate before, during, and after application of $20 \mu \mathrm{M}$ dopamine. Glutamate response amplitude was enhanced during dopamine application. The effect was reversible with washing. A plot of glutamate response amplitude as a function of time is shown in Figure $6 B$; each point represents data from five neurons. Glutamate responses were significantly increased in the five cells tested, as shown in Figure $6 C(410.6 \pm 38 \mathrm{pA}$ for control vs $492.2 \pm 44 \mathrm{pA}$ for dopamine; $p<0.05 ; n=5)$.

Dopamine enhancement of AMPA and NMDA receptormediated currents in hippocampal CA1 neurons is dependent on a rise in postsynaptic $\mathrm{Ca}^{2+}$ (Yang, 2000). We therefore tested whether reducing postsynaptic $\mathrm{Ca}^{2+}$ changes by including the $\mathrm{Ca}^{2+}$ chelator BAPTA in the recording pipette affected the ability of dopamine to modulate EPSCs. After obtaining a stable wholecell recording, at least 15 min was allowed for BAPTA to diffuse into the cell. Under these recording conditions, dopamine did not increase AMPA-mediated (Fig. 7B) or NMDA-mediated (Fig. 7A) EPSCs. A summary of the results is shown in Figure $7 C$ $(38.3 \pm 3$ pA NMDA EPSC in control vs $38.1 \pm 3$ pA in dopamine, $n=5, p>0.5 ; 48.5 \pm 6$ pA AMPA EPSC in control vs $44.8 \pm 7 \mathrm{pA}$ in dopamine, $n=5, p>0.5)$. These results suggest that the increase in EPSC amplitude induced by dopamine involves a $\mathrm{Ca}^{2+}$-dependent postsynaptic mechanism.

\section{Role of PKA and CaMKII in EPSC enhancement}

D1-like receptors are positively coupled to adenylate cyclase. Activation of these receptors will increase cAMP formation and
PKA activity. If PKA was involved in the dopamine-induced EPSC enhancement, blocking PKA activity should inhibit the effect of dopamine. We therefore tested the effect of including the PKA inhibitory peptide PKI [5-24] (Cheng et al., 1986) in the recording pipette $(1 \mu \mathrm{M})$. After obtaining a whole-cell configuration, we waited at least $15 \mathrm{~min}$ to allow the inhibitory peptide to dialyze into the cell. After obtaining control EPSC recordings, 20 $\mu \mathrm{M}$ dopamine was bath applied as described above. No significant changes in EPSC amplitude (255.7 \pm 44 pA for control vs $249.5 \pm$ $42 \mathrm{pA}$ for dopamine; $n=5 ; p>0.5)$ or in decay times $(8.8 \pm 1 \mathrm{vs}$ $8.3 \pm 1 \mathrm{msec} ; n=5 ; p>0.3)$ were observed. Results from five neurons are summarized in Figure $8 A$.

The results presented above indicated that increases in intracellular $\mathrm{Ca}^{2+}$ were required for dopamine modulation of EPSCs. Because CaMKII has been implicated in modulation of both AMPA (Derkach et al., 1999) and NMDA (Leonard et al., 1999) receptors, we examined the effect of the CaMKII inhibitory peptide [281-309] (Colbran et al., 1988) $(10 \mu \mathrm{M})$ on the EPSCs. When the CaMKII inhibitory peptide was included in the recording pipette, no enhancement of EPSC amplitude by dopamine was observed in any of the cells tested $(n=6)$. This is summarized in Figure $8 B(178.9 \pm 36 \mathrm{pA}$ for control vs $183.5 \pm 30 \mathrm{pA}$ for dopamine; $n=6 ; p>0.1)$. There was no significant change in EPSC decay times $(7.7 \pm 2$ vs $7.3 \pm 1 \mathrm{msec} ; n=6 ; p>0.1)$.

\section{Discussion}

The present study demonstrates that dopamine enhances the amplitude of evoked EPSCs in rat PFC. AMPA and NMDA receptormediated EPSCs were increased to a similar extent. This action was attributable to activation of D1-like dopamine receptors. The results of experiments with pressure-applied glutamate and inclusion of BAPTA in the recording pipette indicate a postsynaptic, $\mathrm{Ca}^{2+}$-dependent mechanism. Peptide inhibitors of PKA or CaMKII blocked the enhancing effect of dopamine, suggesting that EPSC enhancement may be attributable to a signaling cascade involving $\mathrm{Ca}^{2+}$, PKA, and CaMKII.

\section{Dopamine modulation of cortical excitability}

The present results indicate that in the presence of bicuculline to block $\mathrm{GABA}_{\mathrm{A}}$ receptors, dopamine can facilitate excitatory synaptic responses in rat layer II-III PFC pyramidal neurons. The facilitation of EPSCs may be more or less pronounced under normal conditions. Dopamine can also inhibit evoked IPSCs in these cells (Gonzalez-Islas and Hablitz, 2001) and could decrease overall cortical excitability by enhancing GABAergic tone via an increase in spontaneous IPSCs (Zhou and Hablitz, 1999) while facilitating specific excitatory inputs. Conversely, dopamine affects dendritic voltage-gated channels (Yang and Seamans, 1996) and may modulate EPSP transmission to the soma. The net effect of dopamine in the intact PFC may thus depend on a number of variables ( site of action, receptor subtype activated, and ion channel affected) and may vary with the spatial-temporal pattern of dopamine release.

\section{Involvement of postsynaptic D1-like receptors}

In the present study, EPSCs were recorded from identified layer II-III pyramidal neurons in medial PFC. Experiments with receptor-specific agonists and antagonists indicated that D1-like receptors were responsible for the observed EPSC enhancement. The D1-like receptor family is composed of the D1 and D5 receptor subtypes. They are preferentially coupled to subtype-specific members of the $\mathrm{G}_{\mathrm{s}}$-like protein family that stimulate the activity of adenylyl cyclase (AC)- and PKA-dependent pathways. D1 re- 
ceptors have been implicated previously in dopamine-glutamate interactions in the PFC (Wang and O'Donnell, 2001). Although the highest density of D1 receptors is in layers V and VI, significant labeling of neurons for D1 mRNA is found in superficial cortical layers (Gaspar et al., 1995; Lu et al., 1997). The present results indicate that dopamine can significantly modulate excitability in upper cortical layers, potentially influencing activity in widespread horizontal and transcallosal pathways as well as deeper cortical layers.

Four lines of evidence indicate that dopamine was acting postsynaptically. There was no change in paired-pulse ratios or EPSC rise times; dopamine enhanced currents evoked by pressure application of glutamate; and including BAPTA in the recording pipette blocked EPSC enhancement. Paired stimulation has been widely used as a tool for evaluation of possible presynaptic changes in synaptic transmission. It is usually accepted, following the classic model of Katz and Miledi (1968), that any change in paired-pulse facilitation reflects a presynaptic change in the release probability or in the number of vesicles available for release. However, it is clear that additional presynaptic and postsynaptic mechanisms may contribute to paired-pulse plasticity. If dopamine had caused a change in paired-pulse ratios, it would have been difficult to interpret unequivocally. Our finding that paired-pulse ratios were unaffected suggests that dopamine was not influencing presynaptic transmitter release. This conclusion is supported by the findings that EPSC rise times were also not altered by dopamine or SKF38393. EPSC decay times were generally unaffected by dopamine, although in six of eight cells, an increase in the decay time for AMPA-mediated EPSCS was observed. The cause for this increase was not apparent. The findings with glutamate application and intracellular BAPTA administration strongly support a postsynaptic mechanism.

\section{Mechanism of action}

Dopamine, acting on D1 receptors, has been reported to modulate postsynaptic responsiveness to glutamate (Levine et al., 1996; Harvey and Lacey, 1997; Umemiya and Raymond, 1997; Cepeda et al., 1998; Calabresi et al., 2000). It is well established that D1 receptors are linked to $\mathrm{AC}$, and that $\mathrm{D} 1$ receptor activation results in an increase in cAMP production and PKA activity. PKA activation has been shown to increase phosphorylation of AMPAtype glutamate receptors (Price et al., 1999; Snyder et al., 2000), an effect known to potentiate currents carried by recombinant AMPA receptors (Roche et al., 1996). Similarly, dopamine receptor activation regulates the phosphorylation states of NMDA receptors (Snyder et al., 1998). D1 receptors, by regulating phosphorylation of both AMPA and NMDA receptors, could modulate the efficacy of excitatory transmission in the PFC.

A rise in postsynaptic $\mathrm{Ca}^{2+}$ was found to be required for the dopamine-mediated enhancement of EPSCs, as reported previously in the hippocampus (Yang, 2000). Inclusion of the CaMKII inhibitory peptide in the recording pipette blocked dopamine enhancement of EPSCs in the present study. Modulation of ion channels by $\mathrm{Ca}^{2+}$ has been broadly demonstrated. Derkach et al. (1999) showed that activation of CaMKII phosphorylates Ser-831 in the glutamate receptor 1 (GluR1) subunit of the AMPA receptors, enhancing its channel conductance in human embryonic kidney (HEK)-293 cells. This phosphorylation is thought to be part of the postsynaptic mechanisms of LTP (Derkach et al., 1999). AMPA receptor-mediated currents are also regulated by CaMKII (Barria et al., 1997). CaMKII has been reported to be associated with NMDA receptors in crude rat brain membranes (Leonard et al., 1999), indicating a broad role for CaMKII modulation of glutamate ionotropic receptors. In the present experiments, it appears that dopamine receptor activation initiated a $\mathrm{Ca}^{2+}$-dependent signaling cascade that involved both PKA and CaMKII. The source of the $\mathrm{Ca}^{2+}$ is unclear. It could result from $\mathrm{Ca}^{2+}$ entry through NMDA or $\mathrm{Ca}^{2+}$-permeable AMPA receptors, voltage-gated $\mathrm{Ca}^{2+}$ channels, or release from intracellular stores. Synaptically released glutamate could also activate metabotropic GluRs (mGluRs), which can result in intracellular calcium release (Masu et al., 1991). NMDA receptors cannot be the sole $\mathrm{Ca}^{2+}$ source, because dopamine potentiated AMPA-mediated EPSCs recorded in the presence of NMDA receptor antagonists. $\mathrm{Ca}^{2+}$ permeable AMPA receptors, lacking the GluR2 subunit, are most prevalent in neocortical interneurons (Jonas et al., 1994; Lambolez et al., 1996; Angulo et al., 1997), although their presence in pyramidal cells cannot be ruled out. Pyramidal neurons are known to have dendritic $\mathrm{Ca}^{2+}$ channels (Markram and Sakmann, 1994), and dopamine can enhance $\mathrm{Ca}^{2+}$ influx (Surmeier et al., 1995). Liu et al. (1992) have reported that D1 receptor activation could lead to an increase in $\mathrm{Ca}^{2+}$ by means of a phosphatidylinositol-dependent pathway and/or through the increase of voltage-dependent $\mathrm{Ca}^{2+}$ entry via $\mathrm{Ca}^{2+}$ channels in rat pituitary cells. A similar mechanism has been demonstrated by Galarraga et al. (1997) and Cepeda et al. (1998) in neostriatal neurons. In brain and kidney cells, D1 receptor agonists also produce an increase in inositol-1,4,5-triphosphate turnover. It is not yet known whether the production of these second messengers involves linkage of D1 receptors to multiple G-proteins or is the result of the activation of alternative D1-like receptor subtypes.

Dopamine modulation of release from intracellular stores remains relatively unexplored. However, D1 receptor stimulation releases calcium from intracellular stores in cells primed by activation of endogenous G-protein-coupled receptors in HEK-293 cells expressing D1 receptors and calcyon, a $24 \mathrm{kDa}$ single transmembrane protein that localizes to dendritic spines of D1 receptor-expressing PFC pyramidal neurons (Lezcano et al., 2000). This is a potentially attractive mechanism, because glutamate, acting at mGluRs, could provide the priming of G-protein receptors. Similarly, activation of D1/D5 receptors stimulates release of calcium from intracellular stores in cultured neocortical neurons (Lezcano and Bergson, 2002).

Combined immunohistochemical-electron microscopic studies of the dopamine innervation of the primate neocortex demonstrated that dopamine terminals form symmetric contacts onto dendritic spines that also receive an excitatory input (Goldman-Rakic et al., 1989). This triadic arrangement has been described in rats (Carr and Sesack, 1996) and provides a means for specifically modulating inputs to individual spines. The present results provide physiological data supporting the idea of a direct gating of excitatory synaptic input to the PFC, as proposed previously (Williams and Goldman-Rakic, 1995). No estimate has been made of the frequency of occurrence of these triads, but classical electron microscopic studies suggest that only 5-30\% of spines receive both symmetric and asymmetric contacts (Jones and Powell, 1969; Beaulieu and Colonnier, 1985). The small increase in EPSC amplitude we observed in response to dopamine is consistent with selective modulation of a small number of terminals. 


\section{References}

Angulo M, Lambolez B, Audinat E, Hestrin S, Rossier J (1997) Subunit composition, kinetic, and permeation properties of AMPA receptors in single neocortical nonpyramidal cells. J Neurosci 17:6685-6696.

Barria A, Muller D, Derkach V, Griffith LC, Soderling TR (1997) Regulatory phosphorylation of AMPA-type glutamate receptors by CaM-KII during long-term potentiation. Science 276:2042-2045.

Beaulieu C, Colonnier M (1985) A laminar analysis of the number of roundasymmetrical synapses on spines, dendritic trunks, and cell bodies in area 17 of the cat. J Comp Neurol 231:180-189.

Berger B, Gaspar P, Verney C (1991) Dopaminergic innervation of the cerebral cortex: unexpected differences between rodents and primates. Trends Neurosci 14:21-27.

Bunney BS, Aghajanian GK (1976) Dopamine and norepinephrine innervated cells in the rat prefrontal cortex: pharmacological differentiation using microiontophoretic techniques. Life Sci 19:1783-1792.

Calabresi P, Gubellini P, Centonze D, Picconi B, Bernardi G, Chergui K, Svenningsson P, Fienberg AA, Greengard P (2000) Dopamine and cAMP-regulated phosphoprotein $32 \mathrm{kDa}$ controls both striatal long-term depression and long-term potentiation, opposing forms of synaptic plasticity. J Neurosci 20:8443-8451.

Carr DB, Sesack SR (1996) Hippocampal afferents to the rat prefrontal cortex: synaptic targets and relation to dopamine terminals. J Comp Neurol 369:1-15.

Cepeda C, Radisavljevic Z, Peacock W, Levine MS, Buchwald NA (1992) Differential modulation by dopamine of responses evoked by excitatory amino acids in human cortex. Synapse 11:330-341.

Cepeda C, Colwell CS, Itri JN, Chandler SH, Levine MS (1998) Dopaminergic modulation of NMDA-induced whole cell currents in neostriatal neurons in slices: contribution of calcium conductances. J Neurophysiol 79:82-94.

Cheng HC, Kemp BE, Pearson RB, Smith AJ, Misconi L, Van Patten SM, Walsh DA (1986) A potent synthetic peptide inhibitor of the cAMPdependent protein kinase. J Biol Chem 26:989-992.

Colbran RJ, Fong YL, Schworer CM, Soderling TR (1988) Regulatory interactions of the calmodulin-binding, inhibitory, and autophosphorylation domains of $\mathrm{Ca}^{2+} /$ calmodulin-dependent protein kinase II. J Biol Chem 263:18145-18151.

Derkach V, Barria A, Soderling TR (1999) $\mathrm{Ca}^{2+} /$ calmodulin-kinase II enhances channel conductance of $\alpha$-amino-3-hydroxy-5-methyl-4isoxazolepropionate type glutamate receptors. Proc Natl Acad Sci USA 96:3269-3274.

Ferron A, Thierry AM, LeDouarin C, Glowinski J (1984) Inhibitory influence of the mesocortical dopaminergic system on spontaneous activity or excitatory response induced from the thalamic mediodorsal nucleus in the rat medial prefrontal cortex. Brain Res 302:257-265.

Fuster JM (1995) Memory in the cerebral cortex: an empirical approach to neural networks in human and non-human primate. Cambridge: MIT.

Galarraga E, Hernandez-Lopez S, Reyes A, Barral J, Bargas J (1997) Dopamine facilitates striatal EPSPs through an L-type $\mathrm{Ca}^{2+}$ conductance. NeuroReport 8:2183-2186.

Gaspar P, Bloch B, Le Moine C (1995) D1 and D2 receptor gene expression in the rat frontal cortex: cellular localization in different classes of efferent neurons. Eur J Neurosci 7:1050-1063.

Goldman-Rakic PS (1995) Cellular basis of working memory. Neuron 14:477-485.

Goldman-Rakic PS, Leranth C, Williams SM, Mons N (1989) Dopamine synaptic complex with pyramidal neurons in primate cerebral cortex. Proc Natl Acad Sci USA 86:9015-9019.

Gonzalez-Islas C, Hablitz JJ (2000) Dopamine enhances evoked EPSCs in layer II/III pyramidal neurons from rat neocortex. Soc Neurosci Abstr 26:1433.

Gonzalez-Islas C, Hablitz JJ (2001) Dopamine inhibition of evoked IPSCs in rat prefrontal cortex. J Neurophysiol 86:2911-2918.

Gurden H, Takita M, Jay TM (2000) Essential role of D1 but not D2 receptors in the NMDA receptor-dependent long-term potentiation at hippocampalprefrontal cortex synapses in vivo. J Neurosci 20:RC106(1-5).

Harvey J, Lacey MG (1997) A postsynaptic interaction between dopamine D1 and NMDA receptors promotes presynaptic inhibition in the rat nucleus accumbens via adenosine release. J Neurosci 17:5271-5280.

Hess G, Jacobs KM, Donoghue JP (1994) N-methyl-D-aspartate receptor mediated component of field potentials evoked in horizontal pathways of rat motor cortex. Neuroscience 61:225-235.

Jonas P, Racca C, Sakmann B, Seeburg PH, Monyer H (1994) Differences in $\mathrm{Ca}^{2+}$ permeability of AMPA-type glutamate receptor channels in neocortical neurons caused by differential GluR-B subunit expression. Neuron 12:1281-1289.

Jones EG, Powell TPS (1969) Morphological variations in the dendritic spines of the neocortex. J Cell Sci 5:509-529.

Katz B, Miledi R (1968) The role of calcium in neuromuscular facilitation. J Physiol (Lond) 195:481-492.

Kerr JND, Wickens JR (2001) Dopamine D-1/D-5 receptor activation is required for long-term potentiation in the rat neostriatum in vitro. J Neurophysiol 85:117-124.

Kolb B (1990) Organization of the neocortex of the rat. In: The cerebral cortex of the rat (Kolb B, Tees RC, eds), pp 21-33. Cambridge: MIT.

Kondo S, Marty A (1998) Differential effects of noradrenaline on evoked spontaneous and miniature IPSCs in rat cerebellar stellate cells. J Physiol (Lond) 509:233-243.

Lambolez B, Ropert N, Perrais D, Rossier J, Hestrin S (1996) Correlation between kinetics and RNA splicing of $\alpha$-amino-3-hydroxy-5methylisoxazole-4-propionic acid receptors in neocortical neurons. Proc Natl Acad Sci USA 93:1797-1802.

Law-Tho D, Hirsch JC, Crepel F (1994) Dopamine modulation of synaptic transmission in rat prefrontal cortex: an in vitro electrophysiological study. Neurosci Res 21:151-160.

Law-Tho D, Desce JM, Crepel F (1995) Dopamine favours the emergence of long-term depression versus long-term potentiation in slices of rat prefrontal cortex. Neurosci Lett 188:125-128.

Leonard AS, Lim IA, Hemsworth DE, Horne MC, Hell JW (1999) Calcium/ calmodulin-dependent protein kinase II is associated with the $N$-methylD-aspartate receptor. Proc Natl Acad Sci USA 96:3239-3244.

Levine MS, Altemus KL, Cepeda C, Cromwell HC, Crawford CA, Ariano MA, Drago J, Sibley DR, Westphal H (1996) Modulatory actions of dopamine on NMDA receptor-mediated responses are reduced in $\mathrm{D}_{1 \mathrm{~A}^{-}}$ deficient mutant mice. J Neurosci 16:5870-5882.

Lewis DA, Sesack SR, Levey AI, Rosenberg DR (1998) Dopamine axons in primate prefrontal cortex: specificity of distribution, synaptic targets, and development. Adv Pharmacol 42:703-706.

Lezcano N, Bergson C (2002) D1/D5 dopamine receptors stimulate intracellular calcium release in primary cultures of neocortical and hippocampal neurons. J Neurophysiol 87:2167-2175.

Lezcano N, Mrzljak L, Eubanks S, Levenson R, Goldman-Rakic P, Bergson C (2000) Dual signaling regulated by calcyon, a D1 dopamine receptor interacting protein. Science 287:1660-1664.

Liu YF, Civelli O, Zhou QY, Albert PR (1992) Cholera toxin-sensitive 3' $5^{\prime}$ cyclic adenosine monophosphate and calcium signals of the human dopamine-D1 receptor: selective potentiation by protein kinase A. Mol Endocrinol 6:1815-1824.

Lu X-Y, Churchill L, Kavlivas PW (1997) Expression of $D_{1}$ receptor mRNA in projections from the forebrain to the ventral tegmental area. Synapse 25:205-214.

Markram H, Sakmann B (1994) Calcium transients in dendrites of neocortical neurons evoked by single subthreshold excitatory postsynaptic potentials via low-voltage-activated calcium channels. Proc Natl Acad Sci USA 91:5207-5211.

Masu M, Tanabe Y, Tsuchida K, Shigemoto R, Nakanishi S (1991) Sequence and expression of a metabotropic glutamate receptor. Nature 349:760-765.

Mrzljak L, Bergson C, Pappy M, Huff R, Levenson R, Goldman-Rakic PS (1996) Localization of dopamine D4 receptors in GABAergic neurons of the primate brain. Physiol Rev 78:189-225.

Otani S, Blond O, Desce JM, Crepel F (1998) Dopamine facilitates longterm depression of glutamatergic transmission in rat prefrontal cortex Neuroscience 85:669-676.

Paxinos G, Watson C (1986) The rat brain in stereotaxic coordinates. Sydney: Academic.

Pirot S, Godbout R, Mantz J, Tassin J-P, Glowinski J, Thierry A-M (1992) Inhibitory effects of ventral tegmental area stimulation on the activity of prefrontal cortical neurons: evidence for the involvement of both dopaminergic and GABAergic components. Neuroscience 49:857-865.

Pitler TA, Alger BE (1992) Cholinergic excitation of GABAergic interneurons in the rat hippocampal slice. J Physiol (Lond) 450:127-142. 
Price CJ, Kim P, Raymond LA (1999) D1 dopamine receptor-induced cyclic AMP-dependent protein kinase phosphorylation and potentiation of striatal glutamate receptors. J Neurochem 73:2441-2446.

Roche KW, O’Brien RJ, Mammen AL, Bernhardt J, Huganir RL (1996) Characterization of multiple phosphorylation sites on the AMPA receptor GluR1 subunit. Neuron 16:1179-1188.

Rubinstein M, Cepeda C, Hurst RS, Flores-Hernandez J, Ariano MA, Falzone TL, Kozell LB, Meshul CK, Bunzow JR, Low MJ, Levine MS, Grandy DK (2001) Dopamine $\mathrm{D}_{4}$ receptor-deficient mice display cortical hyperexcitability. J Neurosci 21:3756-3763.

Sawaguchi T, Goldman-Rakic PS (1994) The role of D1-dopamine receptor in working memory: local injections of dopamine antagonists into the prefrontal cortex of rhesus monkeys performing an oculomotor delayedresponse task. J Neurophysiol 71:515-528.

Sawaguchi T, Matsumura M (1985) Laminar distributions of neurons sensitive to acetylcholine, noradrenaline, and dopamine in the dorsolateral prefrontal cortex of the monkey. Neurosci Res [Suppl] 2:255-273.

Scanziani M, Capogna M, Gahwiler BH, Thompson SM (1992) Presynaptic inhibition of miniature excitatory synaptic currents by baclofen and adenosine in the hippocampus. Neuron 9:919-927.

Scanziani M, Gahwiler BH, Thompson SM (1993) Presynaptic inhibition of excitatory synaptic transmission mediated by $\alpha$-adrenergic receptors in area CA3 of the rat hippocampus in vitro. J Neurosci 13:5393-5401.

Seamans JK, Durstewitz D, Christie BR, Stevens CF, Sejnowski TJ (2001) Dopamine D1/D5 receptor modulation of excitatory synaptic inputs to layer V prefrontal cortex neurons. Proc Natl Acad Sci USA 98:301-306.

Sesack SR, Bunney BS (1989) Pharmacological characterization of the receptor mediating electrophysiological responses to dopamine in the rat medial prefrontal cortex: a microiontophoretic study. J Pharmacol Exp Ther 249:1323-1333.

Snyder GL, Fienberg AA, Huganir RL, Greengard P (1998) A dopamine/D1 receptor/protein kinase A/dopamine- and cAMP-regulated phosphoprotein $\left(M_{\mathrm{r}} 32 \mathrm{kDa}\right) /$ protein phosphatase-1 pathway regulates dephosphorylation of the NMDA receptor. J Neurosci 18:10297-10303.

Snyder GL, Allen PB, Fienberg AA, Valle CG, Huganir RL, Nairn AC, Greengard P (2000) Regulation of phosphorylation of the GluR1 AMPA receptor in the neostriatum by dopamine and psychostimulants in vivo. J Neurosci 20:4480-4488.

Surmeier DJ, Bargas J, Hemmings Jr HC, Nairn AC, Greengard P (1995) Modulation of calcium currents by a $\mathrm{D}_{1}$ dopaminergic protein kinase/ phosphatase cascade in rat neostriatal neurons. Neuron 14:385-397.
Sutor B, Ten Bruggencate G (1990) Ascorbic acid: a useful reductant to avoid oxidation of catecholamines in electrophysiological experiments in vitro? Neurosci Lett 116:287-292.

Thierry AM, Mantz J, Glowinski J (1992) Influence of dopaminergic and noradrenergic afferents on their target cells in the rat medial prefrontal cortex. In: Frontal lobe seizures and epilepsies (Chauvel P, DelgadoEscueta AV, Halgren E, Bancaud J, eds), pp 545-554. New York: Raven.

Umemiya M, Raymond LA (1997) Dopaminergic modulation of excitatory postsynaptic currents in rat neostriatal neurons. J Neurophysiol 78:1248-1255.

Urban NN, Gonzalez-Burgos G, Henze DA, Lewis DA, Barrionuevo G (2002) Selective reduction by dopamine of excitatory synaptic inputs to pyramidal neurons in primate prefrontal cortex. J Physiol (Lond) 593:707-712.

Vincent SL, Khan Y, Benes FM (1993) Cellular distribution of dopamine D1 and D2 receptors in rat medial prefrontal cortex. J Neurosci 13:2551-2564.

Vincent SL, Khan Y, Benes FM (1995) Cellular colocalization of dopamine D1 and D2 receptors in rat medial prefrontal cortex. Synapse 19:112-120.

Wang J, O’Donnell P (2001) $\mathrm{D}_{1}$ dopamine receptors potentiate NMDAmediated excitability increases in layer $\mathrm{V}$ prefrontal cortical pyramidal neurons. Cereb Cortex 11:452-462.

Williams GV, Goldman-Rakic PS (1995) Modulation of memory fields by dopamine D1 receptors in prefrontal cortex. Nature 376:572-575.

Yang CR, Mogenson GJ (1990) Dopaminergic modulation of cholinergic responses in rat medial prefrontal cortex: an electrophysiological study. Brain Res 524:271-281.

Yang CR, Seamans JK (1996) Dopamine $D_{1}$ receptor actions in layers of V-VI rat prefrontal cortex neurons in vitro: modulation of dendriticsomatic signal integration. J Neurosci 16:1922-1935.

Yang S-N (2000) Sustained enhancement of AMPA receptor- and NMDA receptor-mediated currents induced by dopamine D1/D5 receptor activation in the hippocampus: an essential role of postsynaptic $\mathrm{Ca}^{2+}$. Hippocampus 10:57-63.

Zhou F-M, Hablitz JJ (1996) Morphological properties of intracellular labeled layer I neurons in rat neocortex. J Comp Neurol 376:198-213.

Zhou F-M, Hablitz JJ (1999) Dopamine modulation of membrane and synaptic properties of interneurons in rat cerebral cortex. J Neurophysiol 81:967-976. 